prospect of future capital infusions into its faltering economy from future petroleum production and Western investment, Azerbaijan is hoping that its economy can become more productive with the help of trained graduates from the private sector. Only time will tell whether the private university sector will gain the kind of credibility and stability that will allow these institutions to play an important role in the advance of civil society in the former Soviet republics.

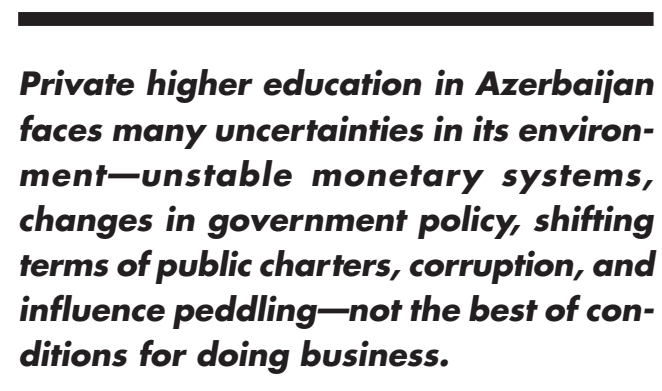

A longer version of this paper includes a case study of a leading private university in Baku, the capital city of Azerbaijan, and is available from the author. As of spring 1996 , this institution is completing its third year of operation and serves approximately 2,000 students who pay as much as $\$ 1,000$ per year in tuition. Most of its faculty formerly served in the state system of higher education and many earned their degrees in Moscow. Almost all instruction is conducted in English. The analysis focuses on the nature of English-language teaching at this university, the attempts of instructors to move away from traditions of direct, didactic teaching, and the overall strategic planning activities, and efforts to promote faculty governance in this institution.

\section{Renewing the Goals of Catholic Higher Education in Asia}

\section{Brother Andrew Gonzalez, FSC}

Brother Andrew Gonzalez, FSC, is president of De La Sale University, 2401 Taft Ave., Manila, Philippines. Fax: 632-526-1403

W hen the first institutions of higher learning were established in Asia, the oldest one being the University of Santo Tomas in the Philippines (1611), their goal was an evangelization-related one, in line with the reality that their founders were for the most part missionary religious workers. To put it as bluntly as possible, even at the risk of oversimplification, these institutions were not founded as centers of intellectual excellence where the propagation and production of knowledge for its own sake were the primary goals. These institutions were seen as a means of attracting the indigenous population toward the new knowledge of the colonial masters and its benefits and in the process maintaining the new links with the institutional Church, allowing a period of further internalization of the new religion in the locals' minds and in their emotions as well as attitudes. This primal motivation seems to be imprinted upon those involved in Catholic education even today for even now, administrators and faculty, especially religious personnel and concerned laymen and laywomen, worry about the faith and morals of their Catholic students in these universities.

Like the learning brought by De Nobili to India and by Ricci to China, higher education was a means of evangelization through attracting nonbelievers to what the Church had to offer in the field of Western knowledge and especially science, in the process keeping believers in a protected atmosphere where their faith could mature. As universities took on a more pragmatic purpose as institutions of training for the professions, Catholic institutions began to offer professional studies, again to attract converts and to keep believers in the faith.

One surmises that the same motivations undergirded Protestant universities in my part of the world, for evangelization was an all-consuming concern. However, because of many factors present in Protestantism but not in Catholicism, the move toward excellence in knowledge for its own sake and in research began much earlier among Protestant institutions. The traditionally intellectually oriented religious-such as the Dominicans and the Jesuits, espe- 
cially the latter-began modernizing their universities earlier, compared to the other religious orders, which were engaged in primary and secondary education and only much later in higher education.

Today there are many Catholic institutions in the Philippines, an increasing number in Indonesia, while Thailand has only a few (none in Hong Kong, Malaysia, and Singapore); Japan and South Korea have quite a few, (although the Protestant institutions outnumber the Catholic); Taiwan has a smaller number, and before 1949 , Mainland China had a few. By and large, these have been teaching institutions, justifying their existence by the scarcity of institutions of higher learning to meet the growing demand from more affluent populations and holding their own because of the inefficiency of many state institutions. However, because of the need for growth, to survive and to compete, the clientele of these institutions is drawn mostly from among non-Catholics; religious thinkers justify this involvement with non-Catholics as the "pre-evangelization" phase under the old missiology, as "ecumenism" under more contemporary thinking in theology.

As universities took on a more pragmatic purpose as institutions of training for the professions, Catholic institutions began to offer professional studies, again to attract converts and to keep believers in the faith.

The need for a paradigm shift, to use this apt but by now hackneyed phrase, becomes more evident as we move into a new century. Asia and the Pacific Rim are the global growth areas for the 21st century; whether or not Catholic universities exist, the demand for education will be there. It will be an educational seller's market in some countries, but is this enough justification for engaging in "Catholic higher education" ( to be implemented by laymen and laywomen because of the scarcity of religious personnel)? In countries where poverty has ceased to be a problem, maintaining universities under the overall banner of "preferential option for the poor" no longer rings true, since poverty is disappearing.

Universities are being opened by industrial firms in Korea and in Japan; with monetary problems no longer a major problem, is the Church presence still needed in these institutions? If one were to respond that the Catholic uni- versity is the site for the Church in dialogue with the modern world, how many universities are needed in each country to carry on this dialogue? Certainly we do not need the multiple institutions in the Philippines. Perhaps only one or at most one per region would meet the need for this dialogue.

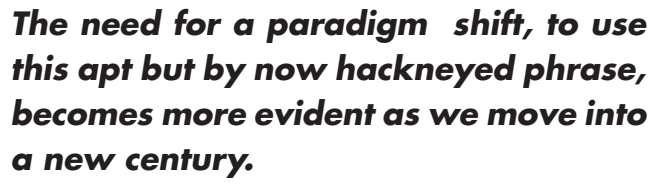

While Catholic universities do much good, it is doubtful if they are really the most effective instruments for evangelizing and keeping the faith; in fact, they become breeding grounds for heretics and liberal theologians! These days, too, with human rights such a live issue, one can no longer legislate moral practice even in relatively closed systems like residential universities. It is doubtful that one can look after young adults, and in so doing, preserve their faith or morals, which was one of the premises for the continuing existence of a Catholic university in the past.

And if Catholic institutions really lack the manpower and material resources to be not only propagators but discoverers of new knowledge, can they justify themselves under the modern demands of what a university should be, in keeping with its distinctive intellectual mission, what John Paul II calls "the apostolate of the mind"? How may apostolic institutions are needed in a society for this apostolate of the mind?

These are questions begging for answers. They are being asked by someone who believes in the Catholic university but for reasons other than those assumed in the past. Clearly, the Catholic university in Asia needs to find a reason for existence besides evangelization and must then face up to the full practical implications that its new purposes will entail. 